\title{
The Potential for Stem Cell Therapy in Diabetes
}

\author{
JURIS J. MEIER, ANIL BHUSHAN, AND PETER C. BUTLER
}

Larry Hillblom Islet Research Center, University of California Los Angeles, David Geffen School of Medicine, Los Angeles, CA 90095

\begin{abstract}
Both type 1 and type 2 diabetes are characterized by a marked deficit in beta-cell mass causing insufficient insulin secretion. Beta-cell replacement strategies may eventually provide a cure for diabetes. Current therapeutic approaches include pancreas and islet transplantation, but the chronic shortage of donor organs restricts this treatment option to a small proportion of affected patients. Moreover, recent evidence shows a progressive decline in beta-cell function after islet transplantation so that most patients have to revert to insulin treatment within a few years. In this article recent progress in the generation, culture and targeted differentiation of human embryonic stem (ES) cells is reviewed, and some of the issues surrounding their use as a source of beta-cells are discussed. (Pediatr Res 59: 65R-73R, 2006)
\end{abstract}

\section{A SOURCE OF BETA-CELLS, THE NEED}

$\mathrm{G}^{\mathrm{l}}$ lucose homeostasis requires finely regulated insulin secretion by pancreatic beta-cells present in islets of Langerhans (1). In health, under fasting basal conditions insulin is secreted at a rate of $\sim 2 \mathrm{pmol} / \mathrm{kg} / \mathrm{min}(2,3)$ and after meal ingestion this rate increases by as much as $\sim 5-10$-fold (4). To accomplish this requires not only normally functioning beta-cells, but also a sufficient number of beta-cells, collectively often referred to as beta-cell mass. In health, the human pancreas contains approximately one million islets, each containing approximately two thousand beta-cells (5-8). Thus, the beta-cells constitute $\sim 1.5 \%$ of the total pancreatic mass (1-2 $\mathrm{g}$ in total) (8). While in humans, an up to $40 \%$ loss of beta-cells can be tolerated without a significant deterioration of glucose tolerance (9), a further reduction in beta-cell mass leads to hyperglycemia.

Type 1 diabetes is caused by autoimmune-mediated destruction of beta-cells (10-16). Longitudinal studies of insulin secretion in humans at risk for type 1 diabetes show declining first phase insulin secretion years before the onset of hyperglycemia which has been interpreted as being due to declining beta-cell mass $(17,18)$. Once hyperglycemia develops as much as $90 \%$ of beta-cells have been lost $(12-14,19,20)$. Some residual insulin secretion may persist in people with longstanding type 1 diabetes (21-24), consistent with autopsy

Received November 18, 2005; accepted December 6, 2005

Correspondence: Peter C. Butler, Larry Hillblom Islet Research Center, UCLA David Geffen School of Medicine, 24-130 Warren Hall, 900 Veteran Avenue, Los Angeles, CA 90095-7073; e-mail: pbutler@mednet.ucla.edu

Supported by grants from the US Public Health Service NIH DK 59579 and 61539 [P.C.B.] and DK68763 [A.B.], the Larry L. Hillblom Foundation, the Juvenile Diabetes Research Foundation (7-2005-1152 [P.C.B.], 1-2005-1174 [A.B.] and 5-2006-330 [A.B.]) and the Deutsche Forschungsgemeinschaft (Me 2096/2-1).

DOI: 10.1203/01.pdr.0000206857.38581.49 studies reporting scattered beta-cells and occasional islets with beta-cells present in patients with long standing type 1 diabetes $(12-14,25)$. Indirect evidence suggests that these beta-cells may be present because of ongoing beta-cell formation, although the source of these cells remains unknown (25).

Type 2 diabetes is also characterized by an $\sim 65 \%$ decrease in beta-cell mass $(9,26)$, associated with a $\sim 10$-fold increase in beta-cell apoptosis $(9,27)$. In contrast to type 1 diabetes this increased apoptosis is not thought to be due to autoimmune disease. Toxic oligomers of human islet amyloid polypeptide (hIAPP) $(9,28,29)$, glucose and FFA-induced toxicity have all been implicated (30-34). A comparable reduction in beta-cell mass in pigs, dogs and non-human primates also leads to hyperglycemia (35-39). Taken together, these data highlight the importance of beta-cell mass for the maintenance of normoglycemia. Therefore, beta-cell replacement is a potential therapy that might reverse rather than simply palliate both type 1 and type 2 diabetes. Pancreas transplantation is effective, improving quality if not duration of life in people with type-1 diabetes (40-42). However, limited organ availability and the risks associated with relatively major surgery and life-long immunosuppression limit the use of this option $(41,42)$. Islet transplantation overcomes the need for major surgery but is far from being a risk-free procedure; it does not overcome the limitation of organ availability and is much less successful than pancreas transplantation at accomplishing sustained insulin independence (43-46). The continued need for an alternative means of replacing beta-cells in people with diabetes has fostered scientific and public interest in the potential of embryonic stem (ES) cells as a potential therapy.

\section{WHY EMBRYONIC STEM CELLS?}

Human ES cells are derived from the inner cell layer of the blastocyst (Fig. 1) $(47,48)$. These cells subsequently give rise to all differentiated cells in the adult through a series of cell fate choices that involve self-renewal and differentiation (4751). Therefore they can theoretically be differentiated into any definitive cell type, including pancreatic beta-cells, when exposed to the appropriate signals in the correct sequence and

Abbreviations: ES cells, embryonic stem cells; FACS, fluorescence-activated cell sorting; GIP, gastric inhibitory polypeptide; GLP-1, glucagon-like peptide 1; hIAPP, human islet amyloid polypeptide; NGN3, neurogenin3; XIAP, X-linked inhibitor of apoptosis protein 


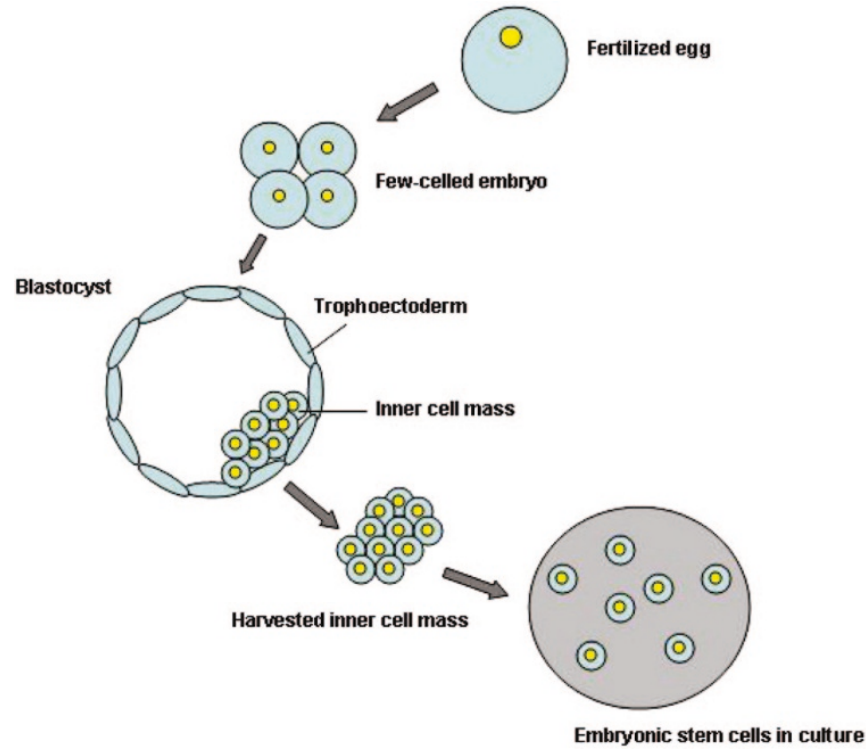

Figure 1. Generation of human embryonic stem cells. A few-celled embryo gives rise to the blastocyst, a structure comprised of an outer cell layer, the trophoectoderm, and the inner cell mass. The inner cell mass is harvested and plated on feeder cells to yield a population of embryonic stem cells. (Figure adapted from Landry et al., J Clin Invest 114:1184-1186, copyright (C) 2004 by the American Society for Clinical Investigation, with permission.)

over the appropriate time periods (pluripotency) (48). Moreover, if the source of such cells was truly unlimited, it would be possible to provide new treatments from time to time as required if the cells were not self renewing once terminally differentiated. To obtain an unlimited supply of human ES cells it is necessary to establish human ES cells lines that behave like primary ES cells.

\section{OBSTACLES ASSOCIATED WITH THE USE OF EMBRYONIC STEM CELLS}

Despite the obvious appeal of ES cell-based beta-cell replacement therapy for diabetes, there are several major obstacles that must be overcome to before this approach can be realistically considered as a therapeutic option.

Ethical and religious sensitivities. There are ethical and religious sensitivities concerning use of human embryos that still hamper the broader use of ES cells for research purposes, and many governments ban or at least highly restrict this kind of research $(52,53)$. The Roman Catholic Church has repeatedly demanded an international ban of human ES cell research, since this requires the destruction of human embryos, and in their view, the human embryo has all the moral rights and protection as any other human being $(54,55)$. Owing to these moral concerns, the United States Congress has enacted a broad ban on federal funding for human ES cell research. Later, this ban was loosened to allow research on human stem cell lines that already existed. A highly debated question is whether stem cells from human embryos should be used to generate stem cell lines, given that they were not suitable for fertilization programs and therefore would otherwise be discarded. The standpoint of the religious authorities on this matter is well exemplified by a recent statement from U.S.

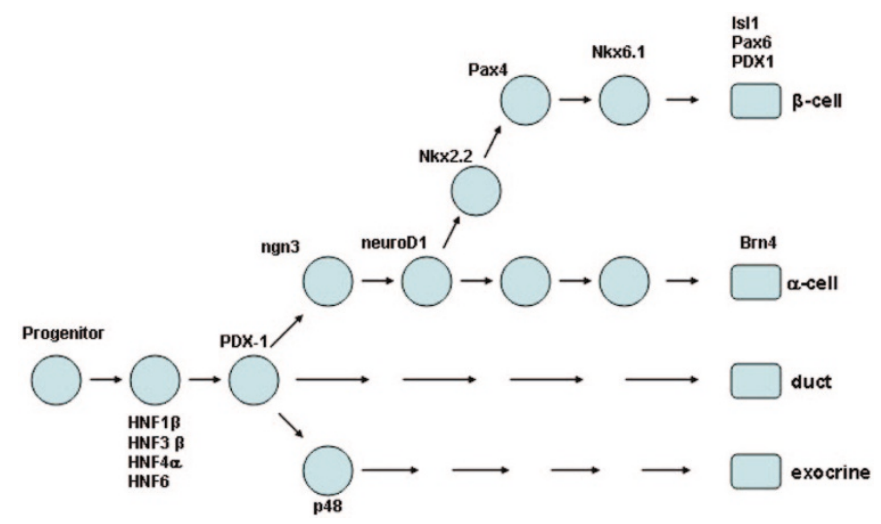

Figure 2. The role of islet transcription factors in endocrine differentiation in the developing pancreas. Figure adapted from Wilson et al., Mech Dev 120:65-80, Copyright $\odot 2003$ by Elsevier Science Ireland Ltd., with permission.

President George W. Bush saying that, "There is no such thing as a spare embryo" (New York Times, May 26, 2005). A central question relating to this discussion is, when an embryo is to be considered dead. Thus, Landry and Zucker recently pointed out that depending on the definition of death before the onset of neural development, a significant fraction of these human embryos will be found to be "organismically" dead (56). Based on this standpoint, using such embryos to generate human stem cell lines would not contradict the ethics of the Catholic Church and other religious authorities. Just recently, two papers have been published describing novel techniques to derive mouse stem cells without affecting the subsequent development of the embryo $(57,58)$. If similar techniques can be applied to human embryos, this may resolve some of the ethical concerns regarding the generation of ES cell line.

Establish and expand cell lines. The first step before ES cells can be used as therapy is to obtain ES cell lines from human embryos and to expand these without loss of their pluripotential properties, or being contaminated in ways that would preclude use as a therapy. ES cell lines have been established from rodents, rabbits, pigs, primates and humans (48,50,51,59-62). Human ES cells have typically been expanded as undifferentiated colonies on feeding layers of mouse embryonic fibroblasts. ES cells differentiate into ectodermal, mesodermal and endodermal structures after removal from this layer (50). The use of mouse fibroblasts as feeding layers has contaminated some of the limited supply of human ES cells available with mouse genes, precluding their therapeutic potential $(50,51,63,64)$. However, it is possible to expand human ES cells without mouse feeder layer cells so that in future human ES cells can be expanded without this problem (65), although obtaining new ES cell lines is limited by the unresolved religious and ethical concerns raised earlier. Thus successful culture of human ES cells over 30 passages has recently been described in the absence of mouse embryonic fibroblasts by using only serum replacement media and high concentrations of basic fibroblast growth factor (66).

Development. The second step before ES cells can be considered as a therapeutic option for diabetes is to establish the means to drive development of the ES cells lines to differentiated and functioning beta-cells. In normal human 
development ES cells are exposed to numerous complex and as yet minimally understood signals to generate fully differentiated beta-cells within the organelle, the islet of Langerhans. These include signals arising from both within the future developing beta-cells to activate transcriptional programs, but perhaps more importantly, neighboring cells that are not destined to form beta-cells can signal to influence progenitor cell differentiation into beta-cells (67-73). In the human embryo this process by definition begins at conception and is ongoing during the first year of life $(74,75)$. Beta-cells develop from progenitor cells arising along with exocrine and ductal tissue in the evolving three-dimensional architecture of the primordial pancreatic bud from the foregut.

During embryonic development the pancreas forms from a ventral and a dorsal bud, protrusions of the primitive gut endoderm that fuse to form the pancreas. Subsequently, a cascade of transcription factors are activated which initiate further development and differentiation toward the specific cell types (Fig. 2). The specific hierarchy of these factors has previously been summarized in an elegant review by Wilson et al (68). A key player in this system is the transcription factor $P D X-1$ (also referred to as ipf1), which is commonly expressed in all pancreatic progenitor cells $(73,76,77)$. Also, $P D X-1$ knock-out mice are characterized by an apancreatic phenotype (76). The cell fates choices of pancreatic progenitors are regulated by Notch signaling through HES1 activation $(76,78,79)$. The transcription factor neurogenin3 (NGN3) plays an essential role in the differentiation of endocrine cells from the pool of pancreatic progenitor cells $(80,81)$. Once NGN3 is activated and the cell is determined toward an endocrine phenotype, a number of different factors control the ultimate fate as an alpha-, beta-, delta- or PP-cell. Specifically, activation of Nkx2.2, Pax4 and Nkx6.1 appears to be crucial for the differentiation of a beta-cell phenotype $(68,82)$.

While there has been considerable progress in establishing some of the transcriptional programs required to develop adult beta-cells, most of the signals that initiate the transcriptional program remain unknown. As yet, little is known about the three-dimensional origins of signals that direct beta-cell development to develop in relation to one another and other cell types in the islet of Langerhans. In embryogenesis the developing beta-cells are organized in relation to developing vascular and neural input. It is likely that signals arising from these orchestrate aspects of islet development and yet inevitably these are not included in ex vivo culture $(83,84)$. To emphasize the importance of extra-cellular signals, it is clear that extra-cellular matrix proteins play a major role in islet cell differentiation (85-87).

Since it takes more than 18 months to establish functional beta-cell mass in developing humans $(75,88)$, it is not yet clear if it will be possible to drive ES cells to a useful mass of beta-cells or beta and other cell type aggregates, ex vivo. A concern is the fact that human ES cells tend to undergo senescence and differentiation within days in culture thereby losing their pluripotency (89).

Rejection. Another obstacle that will have to be overcome before ES cells can be used as therapy is to protect the resulting beta-cells from rejection, to avoid the need for immunosuppression. Theoretically, ES cells can be manipulated ex vivo to induce immune-compatibility with the intended recipient $(90,91)$ avoiding the need for immunosuppression and its attendant side effects $(44,45)$.

Progress to date. Several in vitro studies have demonstrated that it is possible to obtain cells that express insulin from human ES cells $(63,92,93)$. Given the discussion of the challenges that must be overcome above, it is not surprising that functionally useful beta-cells have not yet been obtained from human ES cells $(63,92,93)$. Cells that have been generated from human ES cells that express insulin have been minimally glucose responsive (63). Expression of typical beta-cell markers, such as insulin, GLUT-2 and glucokinase, has been detected in some of these cells $(94,95)$. However, insulin staining in ES cell-derived tissue preparations should be interpreted with caution, because insulin staining can overestimate the proportion of beta-cells, when insulin is present in the culture medium (96). Perhaps not surprisingly, preparations of human ES cells usually consist of a mixture of different cell types and purification of insulin-secreting cells from such cell clusters has proven to be technically difficult (64). Thus, even using various strategies to direct human ES cell differentiation toward a beta-cell-like phenotype, the overall yield of insulin-expressing cells is typically less than 1-3\% of the total cell number. Current attempts to purify those cell populations include fluorescence-activated cell sorting (FACS) as well as the use of magnetic tagged antibodies against specific beta-cell surface markers (64). Alternatively, ES cells can be transfected with genetic constructs that couple the human insulin gene to drug resistance genes (e.g. the neomycin resistance gene). Through these means, beta-cells can be selected according to their resistance to neomycin treatment (64). However, none of these methods has yet yielded a 100\% pure preparation of insulin-secreting cells.

Islets or beta-cells? An unresolved question: Exactly what is the target form that beta-cells should take if successfully developed from human ES cells? Adult pancreatic islets have a complex architecture, with the beta-cells being more preferentially located in the islet core and the other cell types, such as alpha-, delta- and PP-cells, being more abundant in the islet periphery $(4,8)$. The main vascular supply of the islet comes from an arteriole that enters the islet from its beta-cell enriched core, from where the blood is being passed to the islet periphery (8). Also, beta-cells are tightly connected to each other via gap junctions, thereby allowing direct electrical coupling between neighboring cells (97). This specific structure of the islets appears to be important for the coordinated discharge of the different islet hormones $(4,98,99)$. Thus single beta-cells obtained from islets are much less responsive than beta-cells electrically coupled (100). Insulin in health is secreted in discrete secretory bursts, the primary mechanism through which insulin secreted is regulated being the modulation of burst mass (101-105). Moreover insulin secreted per islet at a given stimulus of glucose is substantially increased once the islets are interconnected by a neural network (106). While it is already a considerable challenge to derive functional beta-cells from human ES cells, it would be altogether a more daunting challenge to recapitulate functional islets 


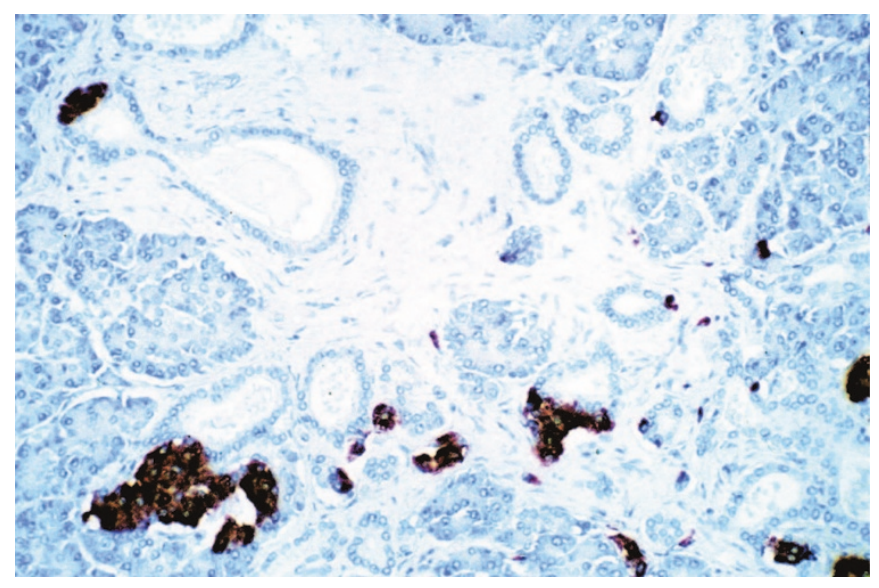

Figure 3. Section of pancreas $(\times 20$ magnification $)$ of a non-diabetic human subject stained for insulin (brown). Numerous pancreatic ducts are shown, with insulin-positive cells present in the duct walls. This finding has often been interpreted as an indicator of new islet formation. Figure reprinted from Butler et al., Diabetes 52:102-110, Copyright (C) 2003 by the American Diabetes Association, Inc., with permission.

from human ES cells. Should beta-cells derived from human ES cells be established in micro cell clusters, or as a single organ? Would such an aggregate of beta-cells be functional, and most importantly not lead to life threatening hypoglycemia?

Where shall we put them? Assuming the limitations outlined above could be overcome, the next question arising would be where to best transplant such human ES-cell derived insulin-secreting cells, cell clusters or islets. Several considerations arise. Human ES cells have the potential to develop teratomas and possibly other cancers (107). Should these cells or cell clusters therefore be encapsulated so that they cannot escape? If so the issues of how large should the capsules be, where should they be implanted, how many would be required, and how long would the cells or cell clusters last in the capsules would have to be addressed.

If the newly formed beta-cells, cell clusters or islets could be transplanted without concern of cancer, then the optimal tissue bed to transplant them would presumably have a relatively high oxygen tension since beta-cells are sensitive to anoxia (108). Also it would need to be established if the cells, cells clusters or islets should direct their secretion into the hepatic portal circulation or the systemic circulation. Given the pivotal role of the liver as the major insulin-responsive organ (109), it seems most desirable to mimic the physiologic route of intra-portal insulin delivery. The fact that intra-portal transplanted islets deliver their insulin directly to the liver rather than into the systemic circulation (110) may therefore provide an argument in favor of intra-portal islet transplantation. Alternatively, the intestinal mucosa may be an attractive transplantation site because of its rich vascularisation and the high local concentrations of potential growth factors such as glucagon-like peptide 1 (GLP-1), gastric inhibitory polypeptide (GIP), GLP-2, gastrin, etc. $(111,112)$, but the surgical implantation of beta-cell clusters into the gut may be technically more demanding.

How long will they last? Based on the recent experiences with islet transplantation in humans, the life span of an islet

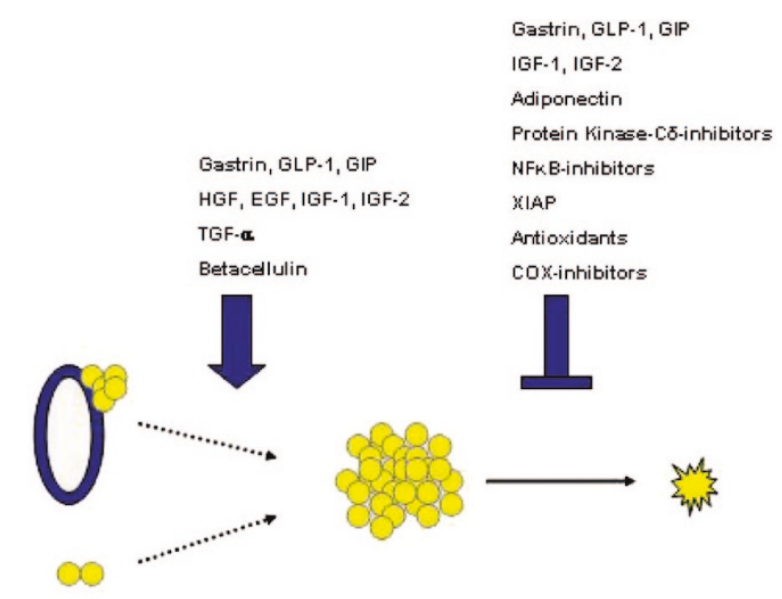

New beta cell formation

Beta cell apoptosis

Figure 4. Beta-cell turnover in adult humans. Beta-cell mass is regulated by the new formation of cells via replication of existing beta-cells or new islet formation from adult stem cells as well as by the rate of beta-cell apoptosis. Deficient beta-cell mass in patients with diabetes may therefore be restored by either enhancing new beta-cell formation or by inhibiting beta-cell apoptosis.

appears to be limited and most patients who had received islet transplantations have to revert to insulin treatment within less than five years (46). Thus, to provide an ultimate cure for diabetes, human ES cell-derived islets or beta-cells would either need to maintain their ability to proliferate, or the transplantation procedure would have to be repeated at regular intervals. Assuming the former possibility, one major challenge would be how to control the proliferative activity of these cells to maintain a physiologic balance between apoptosis and replication. Adult human beta-cells apparently exhibit some plasticity which allows them to respond to increasing secretory demands, e.g. caused by insulin resistance or obesity, by increasing both in number and size $(9,113,114)$. It is unlikely that this complex regulation of beta-cell mass could resemble insulin-secreting cells derived from human ES-cells. Moreover, potential risks imposed by continued replication of ES-cell derived transplants include loss of cell cycle control and the induction of neoplastic cell growth. Consistent with this consideration, the formation of teratomas has been observed in insulin-producing cell lines derived from ES-cells (107). Therefore, maintaining of a physiologic balance between replication and cell death appears to be a major challenge for beta-cell replacement therapies based on ES-cells.

\section{NEW BETA-CELL FORMATION FROM ADULT STEM CELLS}

There is an ongoing controversy regarding the existence of stem cells for new beta-cells in adult individuals (115-118). Such adult stem cells have been suggested to reside in exocrine pancreatic parenchyma (119), pancreatic ducts $(113,120,121)$, pancreatic islets $(122,123)$, liver $(124)$, spleen (125), and in bone marrow (126). However, there is no direct evidence that directly supports the existence of any of these stem cell candidates for beta-cells in humans.

Stem cells in exocrine ducts. Some studies support the idea of new islet formation from exocrine duct cells (113). This 
concept first evolved from the budding of the endocrine pancreas observed during embryonic development (73), and has gained support from different lines of evidence: Thus, endocrine cells can frequently be detected in exocrine ducts in both rodents and humans, and islets adjacent to exocrine ducts are commonly found throughout the pancreas (Fig. 3) $(9,10,14,113,121)$. Moreover, in rodents the number of these ducto-insular complexes is increased during conditions of high secretory demands, e.g. during chronic glucose infusion or after partial pancreatectomy $(121,127)$, implying compensatory new islet formation. In the adult human pancreas, exocrine ducts are often surrounded by areas of fibrous tissue, and the extent of this fibrosis is markedly increased in patients with type 1 diabetes $(12,13,25,128)$. These findings seem to be consistent with the concept of attempted new islet formation and subsequent cell death leading to chronic inflammation in the peri-ductal area. Moreover, the presence of single betacells in the adult human pancreas has been interpreted as an early stage of differentiation of endocrine progenitor cells arising from the ductal epithelium (113). Recently, high levels of PDX-1 (IPF-1) expression were reported in human pancreatic ducts, but not in acinar tissue, suggesting additional similarities between islets and ductal cells (129). However, while all these findings suggest that the ductal epithelium does indeed harbor endocrine progenitor cells, there is no direct evidence, e.g. from lineage tracing studies, for this mechanism. It therefore cannot be excluded with certainty that the co-localization of endocrine cells with ductal cells in the adult pancreas is a coincidence rather than a consequence of ductal cell-derived new beta-cell formation.

Transdifferentiation of exocrine cells. Transdifferentiation of exocrine acinar cells into beta-cells has been proposed as an alternative mechanism for new beta-cell formation in the adult human pancreas $(122,123)$. This concept has been supported by the observation of single beta-cells scattered throughout the exocrine parenchyma in a patient with type 1 diabetes after immunosuppressive treatment (130). Moreover, a number of recent studies have shown that under in vitro conditions acinar tissue can be directed toward a beta-cell like phenotype $(120,131,132)$. However, it is important to note that the appearance of scattered single beta-cells in exocrine parenchyma is a common finding in non-diabetic pancreas as well and that the mere presence of these cells cannot directly prove that they were indeed originated from acinar cells $(9,14)$. Also, directed transdifferentiation into insulin-secreting cells under culture conditions has been described for a number of different cell types and therefore cannot be taken as evidence for in vivo transdifferentiation (133-135).

Epithelial-to-mesenchymal transition. Recently, the concept of epithelial-to-mesenchymal transition has been proposed to account for new beta-cell formation in adult individuals (136). Based on this theory, adult beta-cells dedifferentiate into fibroblast-like cells, which are capable of migrating and proliferating, and subsequently re-differentiate into hormone-expressing islet cells (136). However, given the obvious difficulties of carrying out longitudinal studies on human pancreatic tissue, it is difficult to judge whether this mechanism plays a role for beta-cell regeneration in adult humans.

Bone marrow-derived stem cells. A highly controversial question is, whether new beta-cells could originate from bonemarrow derived cells (126,137-139). Ianus et al performed experiments, in which bone marrow from male donor mice that expressed GFP as well as CRE under the INS2 promotor, was transplanted into female mice that were depleted of their own bone marrow by irradiation. They reported that after 4-6 wk $1.7-3.0 \%$ of the islet beta-cells were derived from bone marrow cells (126). However, other investigators using similar experimental approaches failed to confirm these results (138-140).

\section{REPLICATION AS THE PRIMARY MECHANISM OF NEW BETA-CELL FORMATION?}

Recently, the existence of stem-cells for beta-cells in adult individuals has been challenged by the demonstration that in adult mice beta-cell replication almost exclusively accounts for the formation of new beta-cells (141). Using lineage tracing experiments, Dor et al showed that the vast majority of adult beta-cells were derived from pre-existing beta-cells, thereby ruling out new-beta-cell formation from adult stem cells (141). Moreover, recent studies in cyclin D2 knockout mice demonstrated that replication is the primary mechanism for maintaining postnatal beta-cell mass (71). However, the frequency of $\beta$-cell replication (Ki67 and insulin labeling) in adult human beta-cells is much lower than compared with that in rodents $(9,25)$. It is therefore possible that $\beta$-cell turnover in humans is accomplished from a different source than in rodents.

\section{STRATEGIES TO REPLENISH BETA-CELL MASS FROM ENDOGENOUS SOURCES}

While the sources of new beta-cell formation remain to be elucidated, there is indirect evidence that ongoing beta-cell turnover may be present in adult humans. Beta-cell mass adaptively increases under conditions of high insulin resistance, e.g. in response to obesity or during pregnancy $(9,142,143)$. The invariable presence of some beta-cell apoptosis in adult human pancreas, even in from non-diabetic individuals strongly suggests that some concomitant new betacell formation must be occurring to maintain beta-cell mass $(9,25)$.

Assuming that adult beta-cells do turnover throughout life, beta-cell mass in patients with diabetes could theoretically be replenished by two different approaches: First, by enhancing new beta-cell formation, and second by inhibition of beta-cell apoptosis (Fig. 4). A number of approaches have been suggested to enhance beta-cell mass by increased beta-cell formation. Those include gut hormones, such as gastrin (144146), GLP-1 $(147,148)$, or GIP (149), growth factors, such as hepatocyte growth factors (150), epidermal growth factor (144), IGF-1 or -2 (IGF-1, IGF-2) (151-153), TGF- $\alpha$ $(154,155)$, and growth hormone (153), or other factors such as betacellulin $(154,156)$. Since most of these approaches have been examined either in vitro or in rodent models, it is not yet 
clear if they are capable of enhancing beta-cell formation in humans. Also, newly forming beta-cells have increased vulnerability to apoptosis $(157,158)$. Therefore, enhancing betacell replication and/or new islet formation in patients with type 1 or type 2 diabetes may lead to increased beta-cell apoptosis without a net gain in beta-cell mass.

The alternative approach is to target inhibition of excess beta-cell apoptosis in diabetes. Thus, given the putative ongoing beta-cell formation in adult life and the well documented increased beta-cell apoptosis in both type 1 and type 2 diabetes $(9,25)$, reducing the rate of $\beta$-cell apoptosis may allow for beta-cell regeneration in these patients. In rodent models of type 1 diabetes, inhibition of beta-cell apoptosis leading to partial or total recovery of beta-cell mass has been achieved using many different approaches. In a recent review article, Roep and Atkinson were able to list 192 different approaches to cure diabetes in NOD mice (159). In humans, however, no intervention has accomplished comparable reversal of diabetes (160). To date the best outcome has been prevention or delay of the loss of $\beta$-cell function in patients with new-onset type 1 diabetes treated with $\mathrm{CD}-3$ antibodies (161). In type 2 diabetes, beta-cell apoptosis has been suggested to be caused by the formation of toxic oligomers of hIAPP $(9,29,162-164)$, free radicals, Il1 $\beta$ and lipotoxicity $(30-34 ; 165)$. Although no specific strategies to prevent these putative toxic actions in humans, nonspecific inhibitors of beta-cell apoptosis have been described, many of which exhibit mitogenic properties as well (e.g., GLP-1, gastrin, IGF-1 $(146,148,153))$. Other interesting candidates may be the potassium-channel openers $(166,167)$, adiponectin (168), Inhibition of protein kinase $\mathrm{C}$ delta (169), inhibitors of $\mathrm{NF} \kappa \mathrm{B}$ (170), or the X-linked inhibitor of apoptosis protein (XIAP) (171), antioxidants (Vitamin C, E, NAC) (172), inhibitors of iNOS (173) or anti-inflammatory drugs, such as COX inhibitors or aspirin (174).

Rates of beta-cell turnover in humans. Successful use of the approach of suppression of beta-cell apoptosis to increase beta-cell mass from endogenous $\beta$-cell regeneration requires there to be sufficient new $\beta$-cell formation. Finegood et al attempted to quantitatively assess beta-cell turnover by using the frequencies of $\mathrm{BrdU}$ or thymidine incorporation in $\beta$-cells in rats (175). Based on these data, a turnover rate of $\sim 2 \%$ beta-cells per day was calculated in adult rats (175). However, using continuous long-term BrdU labeling in adult mice, only 1/1,400 beta-cells underwent replication per day (176). Assuming no additional input from new islet formation, transdifferentiation or other potential sources, this would correspond to a proliferation rate of $0.0701 \%$ per day. Thus, even assuming a $0 \%$ rate of beta-cell death, recovery of a $50 \%$ deficit in beta-cell mass would be expected to occur after $\sim 1,429 \mathrm{~d}$, a time period that far exceeds the typical life span of a mouse. In humans, similar calculations are difficult to perform, since BrdU labeling cannot be used for obvious reasons, but based on the reported frequencies of Ki67 labeling, the turnover rate of beta-cells seems to be even slower $(9,25,113,142)$. On the other hand, the increase in beta-cell mass observed in humans during pregnancy (143) implies that this turnover rate can be increased by several-fold under certain conditions even in adult humans.

\section{SUMMARY AND CONCLUSIONS}

Major achievements in the isolation, culture and targeted differentiation of ES cells prompt hopes that it will one day be possible to replenish beta-cell mass in patients with diabetes using ES cell-derived engineered insulin-producing cells. However, in light of ethical concerns and technical obstacles still to be overcome, this approach is unlikely to available as a therapy in the near future. Therefore, alternative methods to increase the number of insulin-secreting beta-cells in patients with diabetes should continue to be explored. The role of adult stem cells in the formation of new beta-cells is controversial, and the origin of such cells is unclear. In rodents the plasticity of the endocrine pancreas in adults and its ability to compensate for an experimental reduction of beta-cell mass suggests that there is ongoing regulated $\beta$-cell turnover in adults which can be targeted to reverse diabetes. The potential for this approach in humans is much less clear but is the basis of active investigation at present.

\section{REFERENCES}

1. Mering JV, Minkowski O 1889 Diabetes mellitus nach Pankreasexstirpation Zschrklin Med 14:404-423.

2. Eaton RP, Allen RC, Schade DS, Erickson KM, Standefer J 1980 Prehepatic insulin production in man: kinetic analysis using peripheral connecting peptide behavior. J Clin Endocrinol Metab 51:520-528

3. Polonsky KS, Pugh W, Jaspan JB, Cohen DM, Karrison T, Tager HS, Rubenstein AH 1984 C-peptide and insulin secretion. Relationship between peripheral concentrations of $\mathrm{C}$-peptide and insulin and their secretion rates in the dog. J Clin Invest 74:1821-1829

4. Meier JJ, Butler PC 2005 Insulin secretion. In: Endocrinology

5. Langerhans P 1869 Beitrag zur mikroskopischen Anatomie der Bauchspeicheldruse. In: Med Dis Berlin

6. Stefan Y, Orci L, Malaisse-Lagae F, Perrelet A, Patel Y, Unger RH 1982 Quantitation of endocrine cell content in the pancreas of non-diabetic and diabetic humans. Diabetes 31:694-700

7. Rahier J, Goebbels RM, Henquin JC 1983 Cellular composition of the human diabetic pancreas. Diabetologia 24:366-371

8. Bonner-Weir S 1991 Anatomy of the islet of Langerhans. In: Samols E (ed) The Endocrine Pancreas, Raven Press New York, pp 15-27.

9. Butler AE, Janson J, Bonner-Weir S, Ritzel R, Rizza RA, Butler PC 2003 Beta-cell deficit and increased beta-cell apoptosis in humans with type 2 diabetes. Diabetes 52:102-110

10. Warren S, Root HF 1925 The pathology of diabetes, with special reference to pancreatic regeneration. Am J Pathol 1:415-430

11. Junker K, Egeberg J, Kromann H, Nerup J 1977 An autopsy study of the islets of Langerhans in acute-onset juvenile diabetes mellitus. Acta Pathol Microbiol Scand 85:699-706

12. Lohr M, Kloppel G 1987 Residual insulin positivity and pancreatic atrophy in relation to duration of chronic type 1 (insulin-dependent) diabetes mellitus and microangiopathy. Diabetologia 30:757-762

13. Pipeleers D, Ling Z 1992 Pancreatic beta-cells in insulin-dependent diabetes. Diabetes Metab Rev 8:209-227

14. Gepts W 1965 Pathologic anatomy of the pancreas in juvenile diabetes mellitus. Diabetes 14:619-633

15. Atkinson MA, Eisenbarth GS 2001 Type 1 diabetes: new perspectives on disease pathogenesis and treatment. Lancet 358:221-229

16. Soeldner JS, Tuttleman M, Srikanta S, Ganda OP, Eisenbarth GS 1985 Insulindependent diabetes mellitus and autoimmunity: islet-cell autoantibodies, insulin autoantibodies, and beta-cell failure. N Engl J Med 313:893-894

17. Srikanta S, Ganda OP, Gleason RE, Jackson RA, Soeldner JS, Eisenbarth GS 1984 Pre-type I diabetes. Linear loss of beta-cell response to intravenous glucose. Diabetes 33:717-720

18. Lo SS, Hawa M, Beer SF, Pyke DA, Leslie RD 1992 Altered islet beta-cell function before the onset of type 1 (insulin-dependent) diabetes mellitus. Diabetologia 35:277-282

19. Hanafusa T, Miyazaki A, Miyagawa J, Tamura S, Inada M, Yamada K, Shinji Y, Katsura H, Yamagata K, Itoh N 1990 Examination of islets in the pancreas biopsy specimens from newly diagnosed type 1 (insulin-dependent) diabetic patients. Diabetologia 33:105-111 
20. Kloppel G, Drenck CR, Oberholzer M, Heitz PU 1984 Morphometric evidence for a striking B-cell reduction at the clinical onset of type 1 diabetes. Virchows Arch A Pathol Anat Histopathol 403:441-452

21. Madsbad S, Krarup T, Reguer L, Faber OK, Binder C 1981 Effect of strict blood glucose control on residual B-cell function in insulin-dependent diabetics. Diabetologia 20:530-534

22. Madsbad S 1983 Prevalence of residual B cell function and its metabolic consequences in Type 1 (insulin-dependent) diabetes. Diabetologia 24:141-147

23. The DCCT Research Group 1987 Effects of age, duration and treatment of insulin-dependent diabetes mellitus on residual beta-cell function: observations during eligibility testing for the Diabetes Control and Complications Trial (DCCT). J Clin Endocrinol Metab 65:30-36.

24. The Diabetes Control and Complications Trial Research Group 1998 Effect of intensive therapy on residual beta-cell function in patients with type 1 diabetes in the diabetes control and complications trial. A randomized, controlled trial. Ann Intern Med 128:517-523.

25. Meier JJ, Bhushan A, Butler AE, Rizza RA, Butler PC 2005 Sustained beta-cell apoptosis in patients with long-standing type 1 diabetes: indirect evidence for islet regeneration? Diabetologia 48:2221-2228

26. Clark A, Wells CA, Buley ID, Cruickshank JK, Vanhegan RI, Matthews DR, Cooper GJ, Holman RR, Turner RC 1988 Islet amyloid, increased A-cells, reduced B-cells and exocrine fibrosis: quantitative changes in the pancreas in type 2 diabetes. Diabetes Res 9:151-159

27. Marchetti P, Del Guerra, S, Marselli L, Lupi R, Masini M, Pollera M, Bugliani M, Boggi U, Vistoli F, Mosca F, Del Prato, S 2004 Pancreatic islets from type 2 diabetic patients have functional defects and increased apoptosis that are ameliorated by metformin. J Clin Endocrinol Metab 89:5535-5541

28. Janson J, Ashley RH, Harrison D, McIntyre S, Butler PC 1999 The mechanism of islet amyloid polypeptide toxicity is membrane disruption by intermediate-sized toxic amyloid particles. Diabetes 48:491-498

29. Kahn SE, Andrikopoulos S, Verchere CB 1999 Islet amyloid: a long-recognized but underappreciated pathological feature of type 2 diabetes. Diabetes 48:241-253

30. Shimabukuro M, Zhou YT, Levi M, Unger RH 1998 Fatty acid-induced beta-cell apoptosis: a link between obesity and diabetes. Proc Natl Acad Sci U S A 95:2498-2502.

31. Robertson RP, Harmon J, Tran PO, Poitout V 2004 Beta-cell glucose toxicity, lipotoxicity, and chronic oxidative stress in type 2 diabetes. Diabetes 53 1:S119S124

32. Robertson RP 2004 Chronic oxidative stress as a central mechanism for glucose toxicity in pancreatic islet beta-cells in diabetes. J Biol Chem 279:42351-42354

33. Maedler K, Oberholzer J, Bucher P, Spinas GA, Donath MY 2003 Monounsaturated fatty acids prevent the deleterious effects of palmitate and high glucose on human pancreatic beta-cell turnover and function. Diabetes 52:726-733

34. Kharroubi I, Ladriere L, Cardozo AK, Dogusan Z, Cnop M, Eizirik DL 2004 Free fatty acids and cytokines induce pancreatic beta-cell apoptosis by different mechanisms: role of nuclear factor-kappaB and endoplasmic reticulum stress. Endocrinology 145:5087-5096

35. Goodner CJ, Koerker DJ, Weigle DS, McCulloch DK 1989 Decreased insulin- and glucagon-pulse amplitude accompanying beta-cell deficiency induced by streptozocin in baboons. Diabetes 38:925-931

36. Kjems LL, Kirby BM, Welsh EM, Veldhuis JD, Straume M, McIntyre SS, Yang D, Lefebvre P, Butler PC 2001 Decrease in beta-cell mass leads to impaired pulsatile insulin secretion, reduced postprandial hepatic insulin clearance, and relative hyperglucagonemia in the minipig. Diabetes 50:2001-2012

37. Larsen MO, Wilken M, Gotfredsen CF, Carr RD, Svendsen O, Rolin B 2002 Mild streptozotocin diabetes in the Gottingen minipig. A novel model of moderate insulin deficiency and diabetes. Am J Physiol Endocrinol Metab 282:E1342-1351

38. Larsen MO, Juhl CB, Porksen N, Gotfredsen CF, Carr RD, Ribel U, Wilken M, Rolin B 2005 Beta-cell function and islet morphology in normal, obese, and obese beta-cell mass-reduced Gottingen minipigs. Am J Physiol Endocrinol Metab 288:E412-421

39. Yasugi H, Mizumoto R, Sakurai H, Honjo I 1976 Changes in carbohydrate metabolism and endocrine function of remnant pancreas after major pancreatic resection. Am J Surg 132:577-580

40. Hopt UT, Drognitz O 2000 Pancreas organ transplantation. Short and long-term results in terms of diabetes control. Langenbecks Arch Surg 385:379-389

41. Venstrom JM, McBride MA, Rother KI, Hirshberg B, Orchard TJ, Harlan DM 2003 Survival after pancreas transplantation in patients with diabetes and preserved kidney function. JAMA 290:2817-2823

42. Larsen JL 2004 Pancreas transplantation: indications and consequences. Endocr Rev 25:919-946

43. Shapiro AM, Lakey JR, Ryan EA, Korbutt GS, Toth E, Warnock GL, Kneteman NM, Rajotte RV 2000 Islet transplantation in seven patients with type 1 diabetes mellitus using a glucocorticoid-free immunosuppressive regimen. N Engl J Med 343:230-238

44. Robertson RP 2004 Islet transplantation as a treatment for diabetes - a work in progress. N Engl J Med 350:694-705

45. Rother KI, Harlan DM 2004 Challenges facing islet transplantation for the treatment of type 1 diabetes mellitus. J Clin Invest 114:877-883

46. Ryan EA, Paty BW, Senior PA, Bigam D, Alfadhli E, Kneteman NM, Lakey JR, Shapiro AM 2005 Five-year follow-up after clinical islet transplantation. Diabetes 54:2060-2069

47. Evans MJ, Kaufman MH 1981 Establishment in culture of pluripotential cells from mouse embryos. Nature 292:154-156
48. Martin GR 1981 Isolation of a pluripotent cell line from early mouse embryos cultured in medium conditioned by teratocarcinoma stem cells. Proc Natl Acad Sci U S A 78:7634-7638

49. Wobus AM, Holzhausen H, Jakel P, Schoneich J 1984 Characterization of a pluripotent stem cell line derived from a mouse embryo. Exp Cell Res 152:212-219

50. Thomson JA, Itskovitz-Eldor J, Shapiro SS, Waknitz MA, Swiergiel JJ, Marshall VS, Jones JM 1998 Embryonic stem cell lines derived from human blastocysts. Science 282:1145-1147

51. Reubinoff BE, Pera MF, Fong CY, Trounson A, Bongso A 2000 Embryonic stem cell lines from human blastocysts: somatic differentiation in vitro. Nat Biotechnol 18:399-404

52. Watson R 2003 Euro MPs threaten UK stem cell research. BMJ 326:838

53. Gruss P 2003 Human ES cells in Europe. Science 301:1017

54. Copland PS 2004 The Roman Catholic Church and embryonic stem cells. J Med Ethics 30:607-608

55. Oakley J 2002 Democracy, embryonic stem cell research, and the Roman Catholic church. Med Ethics 28:22856

56. Landry DW, Zucker HA 2004 Embryonic death and the creation of human embryonic stem cells. J Clin Invest 114:1184-1186

57. Chung Y, Klimanskaya I, Becker S, Marh J, Lu SJ, Johnson J, Meisner L, Lanza R 2006 Embryonic and extraembryonic stem cell lines derived from single mouse blastomeres. Nature 439:216-219

58. Meissner A, Jaenisch R 2006 Generation of nuclear transfer-derived pluripotent ES cells from cloned Cdx2-deficient blastocysts. Nature 439:212-215

59. Graves KH, Moreadith RW 1993 Derivation and characterization of putative pluripotential embryonic stem cells from preimplantation rabbit embryos. Mol Reprod Dev 36:424-433

60. Li M, Zhang D, Hou Y, Jiao L, Zheng X, Wang WH 2003 Isolation and culture of embryonic stem cells from porcine blastocysts. Mol Reprod Dev 65:429-434

61. Thomson JA, Kalishman J, Golos TG, Durning M, Harris CP, Becker RA, Hearn JP 2005 Isolation of a primate embryonic stem cell line. Proc Natl Acad Sci U S A 92:7844-7848

62. Hwang WS, Roh SI, Lee BC, Kang SK, Kwon DK, Kim S, Kim SJ, Park SW, Kwon HS, Lee CK, Lee JB, Kim JM, Ahn C, Paek SH, Chang SS, Koo JJ, Yoon HS, Hwang JH, Hwang YY, Park YS, Oh SK, Kim HS, Park JH, Moon SY, Schatten G 2005 Patient-specific embryonic stem cells derived from human SCNT blastocysts. Science 308:1777-1783. Epub 2005 May 1719

63. Assady S, Maor G, Amit M, Itskovitz-Eldor J, Skorecki KL, Tzukerman M 2001 Insulin production by human embryonic stem cells. Diabetes 50:1691-1697

64. Soria B, Skoudy A, Martin F 2001 From stem cells to beta-cells: new strategies in cell therapy of diabetes mellitus. Diabetologia 44:407-415

65. Klimanskaya I, Chung Y, Meisner L, Johnson J, West MD, Lanza R 2005 Human embryonic stem cells derived without feeder cells. Lancet 365:1636-1641

66. Wang L, Li L, Menendez P, Cerdan C, Bhatia M 2005 Human embryonic stem cells maintained in the absence of mouse embryonic fibroblasts or conditioned media are capable of hematopoietic development. Blood 105:4598-4603

67. Docherty K 2001 Growth and development of the islets of Langerhans: implications for the treatment of diabetes mellitus. Curr Opin Pharmacol 1:641-650

68. Wilson ME, Scheel D, German MS 2003 Gene expression cascades in pancreatic development. Mech Dev 120:65-80

69. Kim SK, MacDonald RJ 2002 Signaling and transcriptional control of pancreatic organogenesis. Curr Opin Genet Dev 12:540-547

70. Sander M, German MS 1997 The beta-cell transcription factors and development of the pancreas. J Mol Med 75:327-340

71. Georgia S, Bhushan A 2004 Beta-cell replication is the primary mechanism for maintaining postnatal beta-cell mass. J Clin Invest 114:963-968

72. Smith SB, Watada H, German MS 2004 Neurogenin3 activates the islet differentiation program while repressing its own expression. Mol Endocrinol 18:142-149. Epub 2003 Oct 2023.

73. Edlund H 2002 Pancreatic organogenesis-developmental mechanisms and implications for therapy. Nat Rev Genet 3:524-532

74. Kassem SA, Ariel I, Thornton PS, Hussain K, Smith V, Lindley KJ, Aynsley-Green A, Glaser B 2001 p57(KIP2) expression in normal islet cells and in hyperinsulinism of infancy. Diabetes 50:2763-2769

75. Bouwens L, Lu WG, De Krijger, R 1997 Proliferation and differentiation in the human fetal endocrine pancreas. Diabetologia 40:398-404

76. Jonsson J, Carlsson L, Edlund T, Edlund H 1994 Insulin-promoter-factor 1 is required for pancreas development in mice. Nature 371:606-609

77. Stoffers DA, Zinkin NT, Stanojevic V, Clarke WL, Habener JF 1997 Pancreatic agenesis attributable to a single nucleotide deletion in the human IPF1 gene coding sequence. Nat Genet 15:106-110

78. Jensen J, Pedersen EE, Galante P, Hald J, Heller RS, Ishibashi M, Kageyama R, Guillemot F, Serup P, Madsen OD 2000 Control of endodermal endocrine development by Hes-1. Nat Genet 24:36-44

79. Lee JC, Smith SB, Watada H, Lin J, Scheel D, Wang J, Mirmira RG, German MS 2001 Regulation of the pancreatic pro-endocrine gene neurogenin3. Diabetes 50:928-936

80. Gu G, Dubauskaite J, Melton DA 2002 Direct evidence for the pancreatic lineage: NGN3 + cells are islet progenitors and are distinct from duct progenitors. Development 129:2447-2457

81. Gradwohl G, Dierich A, LeMeur M, Guillemot F 2000 neurogenin3 is required for the development of the four endocrine cell lineages of the pancreas. Proc Natl Acad Sci U S A 97:1607-1611

82. Sander M, Sussel L, Conners J, Scheel D, Kalamaras J, Dela Cruz, F, Schwitzgebe V, Hayes-Jordan A, German M 2000 Homeobox gene Nkx6.1 lies downstream of 
Nkx2.2 in the major pathway of beta-cell formation in the pancreas. Development 127:5533-5540

83. Lammert E, Cleaver O, Melton D 2001 Induction of pancreatic differentiation by signals from blood vessels. Science 294:564-567

84. Cleaver O, Melton DA 2003 Endothelial signaling during development. Nat Med 9:661-668

85. Wang R, Li J, Lyte K, Yashpal NK, Fellows F, Goodyer CG 2005 Role for beta1 integrin and its associated alpha3, alpha5, and alpha6 subunits in development of the human fetal pancreas. Diabetes 54:2080-2089

86. Geutskens SB, Homo-Delarche F, Pleau JM, Durant S, Drexhage HA, Savino W 2004 Extra-cellular matrix distribution and islet morphology in the early postnatal pancreas: anomalies in the non-obese diabetic mouse. Cell Tissue Res 318:579-589

87. Jiang FX, Cram DS, DeAizpurua HJ, Harrison LC 1999 Laminin-1 promotes differentiation of fetal mouse pancreatic beta-cells. Diabetes 48:722-730

88. Kassem SA, Ariel I, Thornton PS, Scheimberg I, Glaser B 2000 Beta-cell proliferation and apoptosis in the developing normal human pancreas and in hyperinsulinism of infancy. Diabetes 49:1325-1333

89. Halvorsen TL, Beattie GM, Lopez AD, Hayek A, Levine F 2000 Accelerated telomere shortening and senescence in human pancreatic islet cells stimulated to divide in vitro. $\mathrm{J}$ Endocrinol 166:103-109

90. Drukker M, Katchman H, Katz G, Even-Tov Friedman S, Shezen E, Horenstein E, Mandelboim O, Reisner Y, Benvenisty N 2006 Human embryonic stem cells and their differentiated derivatives are less susceptible for immune rejection than adult cells. Stem Cells [Epub ahead of print]

91. Drukker M 2004 Immunogenicity of human embryonic stem cells: can we achieve tolerance? Springer Semin Immunopathol 26:201-213

92. Segev H, Fishman B, Ziskind A, Shulman M, Itskovitz-Eldor J 2004 Differentiation of human embryonic stem cells into insulin-producing clusters. Stem Cells 22:265274

93. Brolen GK, Heins N, Edsbagge J, Semb H 2005 Signals from the embryonic mouse pancreas induce differentiation of human embryonic stem cells into insulinproducing beta-cell-like cells. Diabetes 54:2867-2874

94. Leon-Quinto T, Jones J, Skoudy A, Burcin M, Soria B 2004 In vitro directed differentiation of mouse embryonic stem cells into insulin-producing cells. Diabetologia 47:1442-1451

95. Miyazaki S, Yamato E, Miyazaki J 2004 Regulated expression of PDX-1 promotes in vitro differentiation of insulin-producing cells from embryonic stem cells. Diabetes 53:1030-1037

96. Rajagopal J, Anderson WJ, Kume S, Martinez OI, Melton DA 2003 Insulin staining of ES cell progeny from insulin uptake. Science 299:363

97. Meissner HP 1976 Electrophysiological evidence for coupling between beta-cells of pancreatic islets. Nature 262:502-504

98. Raju B, Cryer PE 2005 Loss of the decrement in intraislet insulin plausibly explains loss of the glucagon response to hypoglycemia in insulin-deficient diabetes: documentation of the intraislet insulin hypothesis in humans. Diabetes 54:757-764

99. Zhou H, Tran PO, Yang S, Zhang T, LeRoy E, Oseid E, Robertson RP 2004 Regulation of alpha-cell function by the beta-cell during hypoglycemia in Wistar rats: the "switch-off" hypothesis. Diabetes 53:1482-1487

100. Aspinwall CA, Lakey JR, Kennedy RT 1999 Insulin-stimulated insulin secretion in single pancreatic beta-cells. J Biol Chem 274:6360-6365

101. Pørksen N, Munn S, Steers J, Vore S, Veldhuis J, Butler P 1995 Pulsatile insulin secretion accounts for $70 \%$ of total insulin secretion during fasting. Am J Physiol 269:E478-E488

102. Porksen N, Munn S, Steers J, Veldhuis JD, Butler PC 1996 Effects of glucose ingestion versus infusion on pulsatile insulin secretion. The incretin effect is achieved by amplification of insulin secretory burst mass. Diabetes 45:1317-1323

103. Pørksen NK, Munn SR, Steers JL, Schmitz O, Veldhuis JD, Butler PC 1996 Mechanisms of sulfonylurea's stimulation of insulin secretion in vivo: selective amplification of insulin secretory burst mass. Diabetes 45:1792-1797

104. Pørksen N, Nyholm B, Veldhuis JD, Butler PC, Schmitz O 1997 In humans at least $75 \%$ of insulin secretion arises from punctuated insulin secretory bursts. Am J Physiol 273:E908-E914

105. Meier JJ, Veldhuis JD, Butler PC 2005 Pulsatile insulin secretion dictates systemic insulin delivery by regulating hepatic insulin extraction in humans. Diabetes 54:1649-1656

106. Pørksen N, Munn S, Ferguson D, O’Brien, T, Veldhuis J, Butler P 1994 Coordinate pulsatile insulin secretion by chronic intra-portally transplanted islets in the isolated perfused rat liver. J Clin Invest 94:219-227

107. Fujikawa T, Oh SH, Pi L, Hatch HM, Shupe T, Petersen BE 2005 Teratoma formation leads to failure of treatment for type I diabetes using embryonic stem cell-derived insulin-producing cells. Am J Pathol 166:1781-1791

108. de Groot M, Schuurs TA, Keizer PP, Fekken S, Leuvenink HG, van Schilfgaarde, R 2003 Response of encapsulated rat pancreatic islets to hypoxia. Cell Transplant 12:867-875

109. DeFronzo RA 1988 Lilly lecture 1987 . The triumvirate: beta-cell, muscle, liver. A collusion responsible for NIDDM. Diabetes 37:667-687

110. Meier JJ, Verldhuis JD, Sutherland D, Hering BJ, Butler PC 2004 Intra-hepatic transplanted islets in humans secrete insulin in a coordinated pulsatile manner that is delivered directly to the liver (abstract). Diabetes 53(Suppl. 2):A35.

111. Ørskov, C, Rabenhćj L, Wettergren A, Kofod H, Holst JJ 1994 Tissue and plasma concentrations of amidated and glycine-extended glucagon-like peptide 1 in humans. Diabetes 43:535-539

112. Schmidt WE 1997 The intestine, an endocrine organ. Digestion 58:56-58

113. Bouwens L, Pipeleers DG 1998 Extra-insular beta-cells associated with ductules are frequent in adult human pancreas. Diabetologia 41:629-633
114. Bonner-Weir S 2001 beta-cell turnover: its assessment and implications. Diabetes 50:S20-S24

115. Soria B, Bedoya FJ, Martin F 2005 Gastrointestinal stem cells. I. Pancreatic stem cells. Am J Physiol Gastrointest Liver Physiol 289:G177-180

116. Hayek A 2004 In search of endocrine progenitor/stem cells in the human pancreas. Pediatr Diabetes 5:70-74

117. Halban PA 2004 Cellular sources of new pancreatic beta-cells and therapeutic implications for regenerative medicine. Nat Cell Biol 6:1021-1025

118. Bonner-Weir S, Weir GC 2005 New sources of pancreatic beta-cells. Nat Biotechnol 23:857-861

119. Yalniz M, Pour PM 2005 Are there any stem cells in the pancreas? Pancreas 31:108-118

120. Bonner-Weir S, Taneja M, Weir GC, Tatarkiewicz K, Song KH, Sharma A, O’Neil, JJ 2000 In vitro cultivation of human islets from expanded ductal tissue. Proc Natl Acad Sci U S A 97:7999-8004

121. Bonner-Weir S, Baxter LA, Schuppin GT, Smith FE 1993 A second pathway for regeneration of adult exocrine and endocrine pancreas. A possible recapitulation of embryonic development. Diabetes 42:1715-1720

122. Abraham EJ, Kodama S, Lin JC, Ubeda M, Faustman DL, Habener JF 2004 Human pancreatic islet-derived progenitor cell engraftment in immunocompetent mice. Am J Pathol 164:817-830

123. Abraham EJ, Leech CA, Lin JC, Zulewski H, Habener JF 2002 Insulinotropic hormone glucagon-like peptide-1 differentiation of human pancreatic islet-derived progenitor cells into insulin-producing cells. Endocrinology 143:3152-3161

124. Sapir T, Shternhall K, Meivar-Levy I, Blumenfeld T, Cohen H, Skutelsky E, Eventov-Friedman S, Barshack I, Goldberg I, Pri-Chen S, Ben-Dor L, PolakCharcon S, Karasik A, Shimon I, Mor E, Ferber S 2005 Cell-replacement therapy for diabetes: generating functional insulin-producing tissue from adult human liver cells. Proc Natl Acad Sci U S A 102:7964-7969

125. Kodama S, Kuhtreiber W, Fujimura S, Dale EA, Faustman DL 2003 Islet regeneration during the reversal of autoimmune diabetes in NOD mice. Science 302:1223-1227

126. Ianus A, Holz GG, Theise ND, Hussain MA 2003 In vivo derivation of glucosecompetent pancreatic endocrine cells from bone marrow without evidence of cell fusion. J Clin Invest 111:843-850

127. Lipsett M, Finegood DT 2002 beta-cell neogenesis during prolonged hyperglycemia in rats. Diabetes 51:1834-1841

128. Vacca JB, Henke WJ, Knight WA Jr 1964 The exocrine pancreas in diabetes mellitus. Ann Intern Med 61:242-247.

129. Heimberg H, Bouwens L, Heremans Y, Van De Casteele, M, Lefebvre V, Pipeleers D 2000 Adult human pancreatic duct and islet cells exhibit similarities in expression and differences in phosphorylation and complex formation of the homeodomain protein Ipf-1. Diabetes 49:571-579

130. Kuroda A, Yamasaki Y, Imagawa A 2003 Beta-cell regeneration in a patient with type 1 diabetes mellitus who was receiving immunosuppressive therapy. Ann Intern Med 139:W81

131. Bogdani M, Lefebvre V, Buelens N, Bock T, Pipeleers-Marichal M, In't Veld P, Pipeleers D 2003 Formation of insulin-positive cells in implants of human pancreatic duct cell preparations from young donors. Diabetologia 46:830-838

132. Hui H, Wright C, Perfetti R 2001 Glucagon-like peptide 1 induces differentiation of islet duodenal homeobox-1-positive pancreatic ductal cells into insulin-secreting cells. Diabetes 50:785-796

133. Li WC, Horb ME, Tosh D, Slack JM 2005 In vitro transdifferentiation of hepatoma cells into functional pancreatic cells. Mech Dev 122:835-847

134. Cao LZ, Tang DQ, Horb ME, Li SW, Yang LJ 2004 High glucose is necessary for complete maturation of PDX1-VP16-expressing hepatic cells into functional insulin-producing cells. Diabetes 53:3168-3178

135. Tang DQ, Cao LZ, Burkhardt BR, Xia CQ, Litherland SA, Atkinson MA, Yang LJ 2004 In vivo and in vitro characterization of insulin-producing cells obtained from murine bone marrow. Diabetes 53:1721-1732

136. Gershengorn MC, Hardikar AA, Wei C, Geras-Raaka E, Marcus-Samuels B, Raaka BM 2004 Epithelial-to-mesenchymal transition generates proliferative human islet precursor cells. Science 306:2261-2264

137. Tessem JS, DeGregori J 2004 Roles for bone-marrow-derived cells in beta-cell maintenance. Trends Mol Med 10:558-564

138. Lechner A, Yang YG, Blacken RA, Wang L, Nolan AL, Habener JF 2004 No evidence for significant transdifferentiation of bone marrow into pancreatic betacells in vivo. Diabetes 53:616-623

139. Hess D, Li L, Martin M, Sakano S, Hill D, Strutt B, Thyssen S, Gray DA, Bhatia M 2003 Bone marrow-derived stem cells initiate pancreatic regeneration. Nat Biotechnol 21:763-770

140. Mathews V, Hanson PT, Ford E, Fujita J, Polonsky KS, Graubert TA 2004 Recruitment of bone marrow-derived endothelial cells to sites of pancreatic betacell injury. Diabetes 53:91-98

141. Dor Y, Brown J, Martinez OI, Melton DA 2004 Adult pancreatic beta-cells are formed by self-duplication rather than stem-cell differentiation. Nature 429:41-46

142. Bouwens L, Rooman I 2005 Regulation of pancreatic beta-cell mass. Physiol Rev 85:1255-1270

143. Van Assche FA, Aerts L, De Prins, F 1978 A morphological study of the endocrine pancreas in human pregnancy. Br J Obstet Gynaecol 85:818-820

144. Suarez-Pinzon WL, Lakey JR, Brand SJ, Rabinovitch A 2005 Combination therapy with epidermal growth factor and gastrin induces neogenesis of human islet $\{$ beta\}-cells from pancreatic duct cells and an increase in functional $\{$ beta $\}$-cell mass. J Clin Endocrinol Metab 90:3401-3409 
145. Rooman I, Bouwens L 2004 Combined gastrin and epidermal growth factor treatment induces islet regeneration and restores normoglycaemia in C57B16/J mice treated with alloxan. Diabetologia 47:259-265

146. Rooman I, Lardon J, Bouwens L 2002 Gastrin stimulates beta-cell neogenesis and increases islet mass from transdifferentiated but not from normal exocrine pancreas tissue. Diabetes 51:686-690

147. Buteau J, Foisy S, Joly E, Prentki M 2003 Glucagon-like peptide 1 induces pancreatic beta-cell proliferation via transactivation of the epidermal growth factor receptor. Diabetes 52:124-132

148. Meier JJ, Nauck MA 2005 Glucagon-like peptide 1(GLP-1) in biology and pathology. Diabetes Metab Res Rev 21:91-117

149. Trümper A, Trümper K, Trusheim H, Arnold R, Göke B, Horsch D 2001 Glucosedependent insulinotropic polypeptide is a growth factor for beta (INS-1) cells by pleiotropic signaling. Mol Endocrinol 15:1559-1570

150. Beattie GM, Montgomery AM, Lopez AD, Hao E, Perez B, Just ML, Lakey JR, Hart ME, Hayek A 2002 A novel approach to increase human islet cell mass while preserving beta-cell function. Diabetes 51:3435-3439

151. Lingohr MK, Dickson LM, McCuaig JF, Hugl SR, Twardzik DR, Rhodes CJ 2002 Activation of IRS-2-mediated signal transduction by IGF-1, but not TGF-alpha or EGF, augments pancreatic beta-cell proliferation. Diabetes 51:966-976

152. Rabinovitch A, Quigley C, Russell T, Patel Y, Mintz DH 1982 Insulin and multiplication stimulating activity (an insulin-like growth factor) stimulate islet (beta-cell replication in neonatal rat pancreatic monolayer cultures. Diabetes 31:160-164

153. Rhodes CJ 2000 IGF-I and GH post-receptor signaling mechanisms for pancreatic beta-cell replication. J Mol Endocrinol 24:303-311

154. Huotari MA, Palgi J, Otonkoski T 1998 Growth factor-mediated proliferation and differentiation of insulin-producing INS-1 and RINm5F cells: identification of betacellulin as a novel beta-cell mitogen. Endocrinology 139:1494-1499

155. Movassat J, Beattie GM, Lopez AD, Portha B, Hayek A 2003 Keratinocyte growth factor and beta-cell differentiation in human fetal pancreatic endocrine precursor cells. Diabetologia 46:822-829

156. Shing Y, Christofori G, Hanahan D, Ono Y, Sasada R, Igarashi K, Folkman J 1993 Betacellulin: a mitogen from pancreatic beta-cell tumors. Science 259:1604-1607

157. Ritzel RA, Butler PC 2003 Replication increases beta-cell vulnerability to human islet amyloid polypeptide-induced apoptosis. Diabetes 52:1701-1708

158. Meier JJ, Ritzel RA, Maedler K, Gurlo T, Butler PC 2005 Increased vulnerability of newly forming beta-cells to cytokine-induced cell death. Diabetologia 2:1-7

159. Roep BO, Atkinson M 2004 Animal models have little to teach us about type 1 diabetes: 1. In support of this proposal. Diabetologia 47:1650-1656

160. Greenbaum CJ 2002 Type 1 diabetes intervention trials: what have we learned? A critical review of selected intervention trials. Clin Immunol 104:97-104

161. Keymeulen B, Vandemeulebroucke E, Ziegler AG, Mathieu C, Kaufman L, Hale G, Gorus F, Goldman M, Walter M, Candon S, Schandene L, Crenier L, De Block, C, Seigneurin JM, De Pauw, P, Pierard D, Weets I, Rebello P, Bird P, Berrie E, Frewin M, Waldmann H, Bach JF, Pipeleers D, Chatenoud L 2005 Insulin needs after CD3-antibody therapy in new-onset type 1 diabetes. N Engl J Med 352:25982608

162. Butler AE, Janson J, Soeller WC, Butler PC 2003 Increased beta-cell apoptosis prevents adaptive increase in beta-cell mass in mouse model of type 2 diabetes: evidence for role of islet amyloid formation rather than direct action of amyloid. Diabetes 52:2304-2314

163. O’Brien, TD, Butler PC, Westermark P, Johnson KH 1993 Islet amyloid polypeptide: a review of its biology and potential roles in the pathogenesis of diabetes mellitus. Vet Pathol 30:317-332

164. Janson J, Ashley RH, Harrison D, McIntyre S, Butler PC 1999 The mechanism of islet amyloid polypeptide toxicity is membrane disruption by intermediate-sized toxic amyloid particles. Diabetes 48:491-498

165. Maedler K, Sergeev P, Ris F, Oberholzer J, Joller-Jemelka HI, Spinas GA, Kaise N, Halban PA, Donath MY 2002 Glucose-induced beta-cell production of IL-1beta contributes to glucotoxicity in human pancreatic islets. J Clin Invest 110:851-860

166. Ritzel RA, Hansen JB, Veldhuis JD, Butler PC 2004 Induction of beta-cell rest by a Kir6.2/SUR1-selective K(ATP)-channel opener preserves beta-cell insulin stores and insulin secretion in human islets cultured at high $(11 \mathrm{mM})$ glucose. J Clin Endocrinol Metab 89:795-805

167. Maedler K, Storling J, Sturis J, Zuellig RA, Spinas GA, Arkhammar PO, MandrupPoulsen T, Donath MY 2004 Glucose- and interleukin-1beta-induced beta-cell apoptosis requires $\mathrm{Ca} 2+$ influx and extra-cellular signal-regulated kinase (ERK) $1 / 2$ activation and is prevented by a sulfonylurea receptor 1 /inwardly rectifying $\mathrm{K}+$ channel 6.2 (SUR/Kir6.2) selective potassium channel opener in human islets. Diabetes 53:1706-1713

168. Rakatzi I, Mueller H, Ritzeler O, Tennagels N, Eckel J 2004 Adiponectin counteracts cytokine- and fatty acid-induced apoptosis in the pancreatic beta-cell line INS-1. Diabetologia 47:249-258

169. Carpenter L, Cordery D, Biden TJ 2002 Inhibition of protein kinase C delta protects rat INS-1 cells against interleukin-1beta and streptozotocin-induced apoptosis. Diabetes 51:317-324

170. Baker MS, Chen X, Cao XC, Kaufman DB 2001 Expression of a dominant negative inhibitor of NF-kappaB protects MIN6 beta-cells from cytokine-induced apoptosis. J Surg Res 97:117-122

171. Emamaullee JA, Rajotte RV, Liston P, Korneluk RG, Lakey JR, Shapiro AM, Elliott JF 2005 XIAP overexpression in human islets prevents early posttransplant apoptosis and reduces the islet mass needed to treat diabetes. Diabetes 54:25412548

172. Beattie GM, Leibowitz G, Lopez AD, Levine F, Hayek A 2000 Protection from cell death in cultured human fetal pancreatic cells. Cell Transplant 9:431-438

173. Han X, Sun Y, Scott S, Bleich D 2001 Tissue inhibitor of metalloproteinase-1 prevents cytokine-mediated dysfunction and cytotoxicity in pancreatic islets and beta-cells. Diabetes 50:1047-1055

174. Jang JH, Surh YJ 2005 Beta-amyloid-induced apoptosis is associated with cyclooxygenase-2 up-regulation via the mitogen-activated protein kinase-NF-kappaB signaling pathway. Free Radic Biol Med 38:1604-1613

175. Finegood DT, Scaglia L, Bonner-Weir S 1995 Dynamics of beta-cell mass in the growing rat pancreas. Estimation with a simple mathematical model. Diabetes 44:249-256

176. Teta M, Long SY, Wartschow LM, Rankin MM, Kushner JA 2005 Very slow turnover of beta-cells in aged adult mice. Diabetes 54:2557-2567 